\title{
98. FIRST RECORD OF THE EPIZOIC RED SEAWEED POLYSIPHONIA CARETTIA HOLLENBERG IN THE MEDITERRANEAN SEA
}

\author{
José C. BÁEZ, Juan A. CAMIÑAS, Julio VALEIRAS, \\ Francisco CONDE \& Antonio FLORES-MOYA
}

Primera cita del alga roja epizoica Polysiphonia carettia Hollenberg en el mar Mediterráneo

Key words. Caretta caretta, epibionts, Mediterranean Sea, Polysiphonia carettia.

Palabras claves. Caretta caretta, epibiontes, Mar Mediterráneo, Polysiphonia carettia.

Pelagic animals, such as cetaceans and sea turtles, are a singular habitat for growth of benthic organisms. The loggerhead turtle, Caretta caretta (Linnaeus, 1758), is a species that can sometimes become an "ecosystem" itself because it support a very rich flora (Cribb, 1969; Abel Sentíes et al., 1999) and fauna (Frazier et al., 1985; Caine, 1986; Frick et al., 1998; Frick et al., 2000) occurring as epizoic organisms.

Several studies on epibionts of loggerhead turtles have been carried out from samples collected on female individuals during egg laying events that took place on beaches. Dodd (1988) found 5 genera of seaweeds growing on $C$. caretta, but they were identified in that paper only as green or red algae, without specific designation. Ninety-three species of epibionts (including 7 identified genera of algae as well as other unidentified green algae and diatoms) have been recorded on $C$. caretta from the North American shores of the Atlantic Ocean (Caine, 1986; Frick et al., 1998). Abel Sentíes et al. (1999) reported 37 species of seaweeds growing on $C$. caretta from the Caribean coasts of Mexico. Recently, Frick et al. (2000) found 7 new algal species on $C$. caretta, among which an unidentified green alga.

Frazier et al. (1985) carried out a revision of the epibiont molluscs of $C$. caretta from the eastern Mediterranean Sea mentioning the presence of Sphacelaria tribuloides Menegh., Chaetomorpha linum (O.F. Müller) Kütz., Cladophora sp. and Polysiphonia sp. As far as we know, this is the only study of epibionts of C. caretta carried out in the Mediterranean Sea.

We now report the first record of Polysiphonia carettia Hollenberg in the Mediterranean Sea. The samples were obtained from two individuals of loggerhead turtle. Both animals had a shell $39 \mathrm{~cm}$ in minimum strength

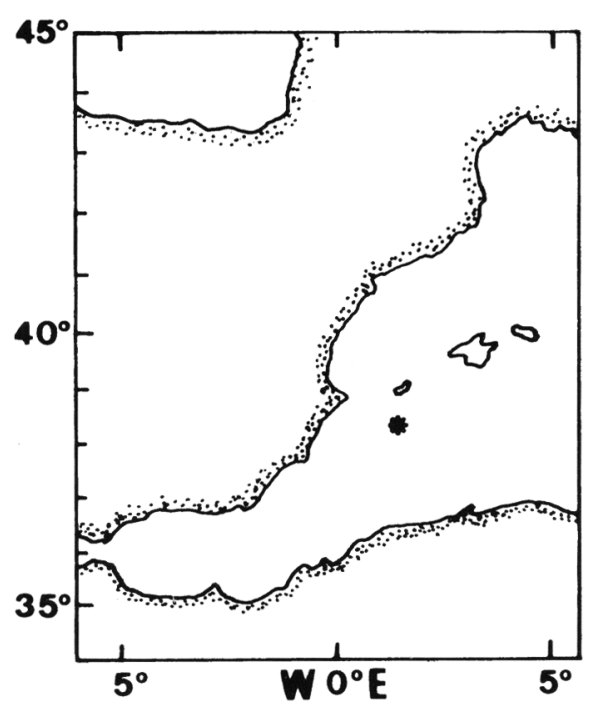

Figure 1. Site of collection of Polysiphonia carettia Hollenberg, epizoic on loggerhead turtle, Caretta caretta (Linnaeus, 1758). 


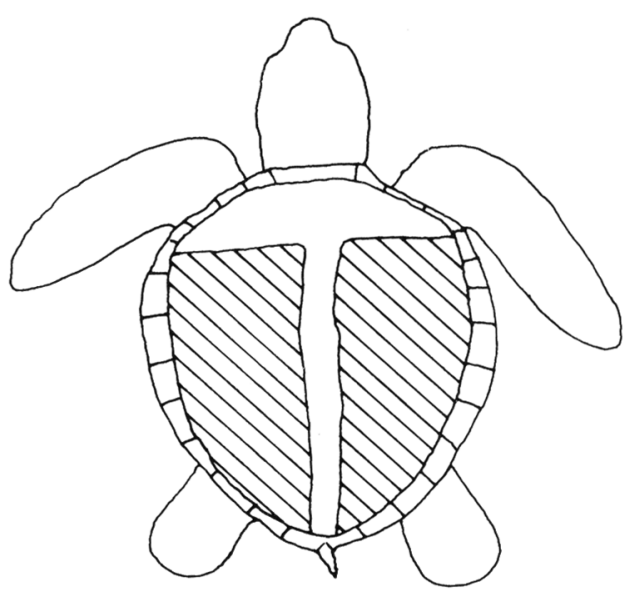

Figure 2. Distribution of Polysiphonia carettia Hollenberg on the loggerhed turtle carapace (oblique lines area).

carapace length (MSCL); therefore, they were probably young individuals because the shell of adult individuals usually measures around $74 \mathrm{~cm}$ in MSCL (Márquez, 1990). They were captured by a spanish longline vessel on October 30th 1999, at 38 $12^{\prime} 69^{\prime \prime} \mathrm{N}$ $001^{\circ} 29^{\prime} 62^{\prime \prime} \mathrm{E}$ (fig. 1). The algae, distributed on the carapace as shown in figure 2 , were collected by scraping the shell carapace of the turtles with a diver's knife. The samples were preserved in $4 \%$ formalin-seawater. They were deposited at Herbarium of the Department of Plant Biology, University of Málaga (MGC Phyc). They were a cession from the Instituto Español de Oceanografía. The turtles were handled carefully in order to preserve the health of the animals.

Polysiphonia carettia Hollenberg (Ceramiales, Rhodomelaceae), MGC Phyc 3742

This species is characterized by its redbrown, uncorticated thallus of $0.5-4 \mathrm{~cm}$ in length, with four pericentral cells surrounding one axial cell, which is smaller in diameter than the pericentral cells (fig. 3.1). The thallus present creeping axes attached by unicellular rhizoids, which initially are in open connection with pericentral cells (fig. 3.2) and, when fully developed, cut off by a cross wall (fig. 3.3). Erect axes have a sparse, irregular branching pattern in the basal and middle portions, whereas the branching is irregular and dense in the distal part. Erect segments are longer than their width (ratio length/width=1.3) and bear deciduous trichoblasts. Tetrasporangia are spherical and are disposed in a spiral series in the distal branches (fig. 3.4); they measure over $40-43 \mu \mathrm{m}$ in diameter. Cystocarps are ovoid-urceolate, with a short peduncle, and measure up to $216 \mu \mathrm{m}$ in length and $144 \mu \mathrm{m}$ in diameter. The pericarp is formed by irregularly distributed polygonal cells similar to the cells of the ostiole (fig. 3.5). The carpospores are pyriform and up to $70-80 \mu \mathrm{m}$ in length and 30 $33 \mu \mathrm{m}$ in diameter. No spermatangial branches were found.

Polysiphonia carettia has been reported on the shells of nesting loggerhead turtles in California (Hollenberg, 1971), Canary Islands (Rojas-González et al., 1994) and the Caribbean Sea (Abel Sentíes et al., 1999). The geographical distribution of $P$. carettia is extended with this study to the Mediterranean Sea.

In the Northern Hemisphere, loggerhead turtles make use of two nesting regions in the north Atlantic Ocean and in the Mediterranean Sea: the one is located on the southeastern shores of the USA and the Gulf of Mexico; the other one in the eastern Mediterranean (Margaritoulis, 1982; Márquez, 1990). It has been proposed that the population from the western Mediterranean Sea contains individuals from both nesting regions, which use this area (and mainly surrounding Balearic Islands) as a feeding area, particularly during spring and summertime (Camiñas, 1997a). Previously this species was recorded only from in the Atlantic Ocean. Although Frazier et al. (1985) recorded 

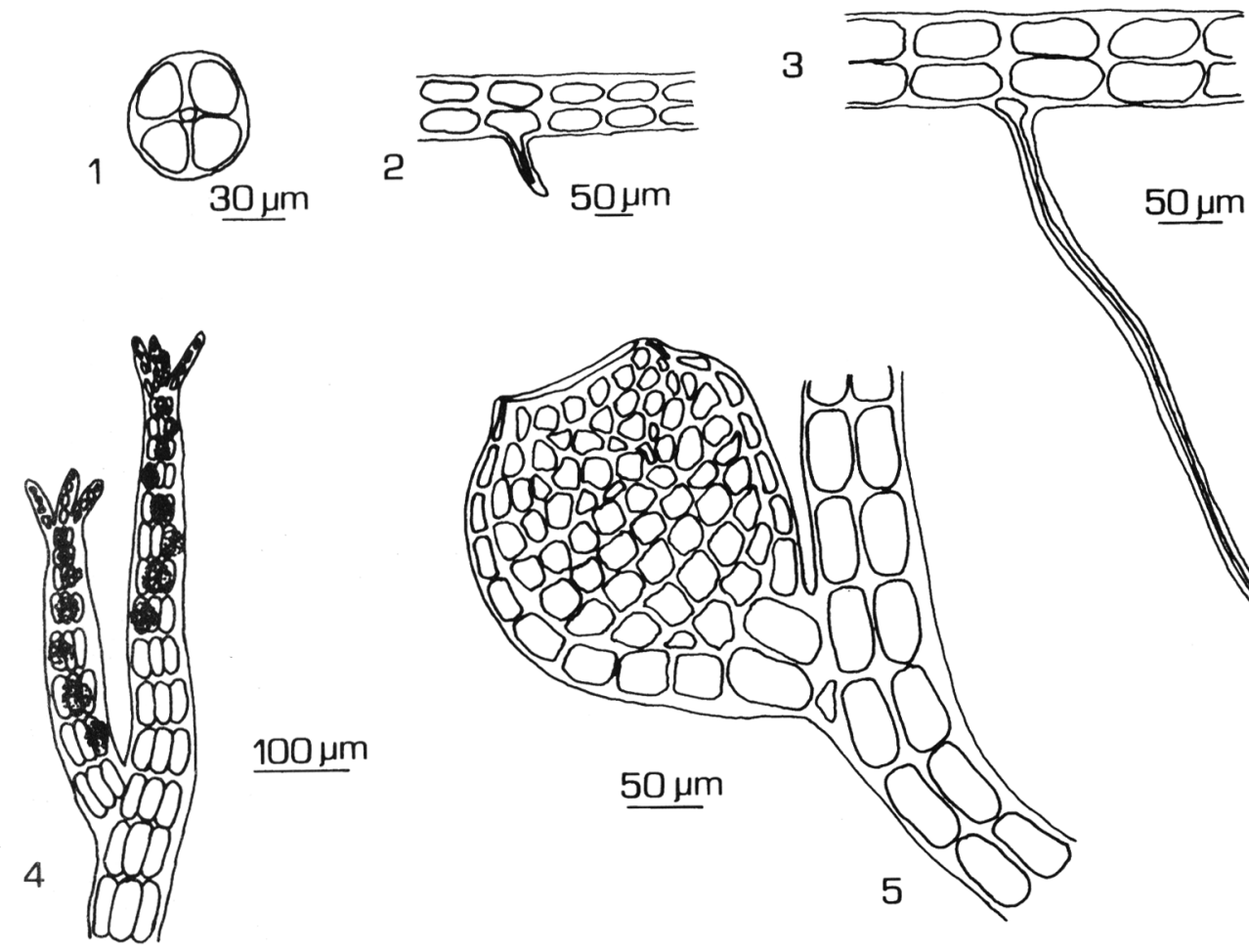

Figure 3. Polysiphonia carettia Hollenberg. 1, cross section of axes; 2-3, postrate axes with unicellular rhizoid; 4 , tetrasporangial branches; 5 , branch with cystocarp.

Polysiphonia sp. growing on Ostrea edulis Linnaeus (occurring as an epibiont on $C$. caretta in the eastern Mediterranean Sea), we think that species could not be $P$. carettia because this taxon has always been found on the loggerhead turtle and not on any other substratum (Hollenberg, 1971; Hollenberg and Norris, 1977; Rojas-González et al., 1994; Abel Sentíes et al., 1999). It is known that the populations of loggerhead turtles from the eastern Mediterranean Sea are genetically isolated from the population from the western area (Laurent et al., 1998). Thus, the finding of $P$. carettia growing on young individual of loggerhead turtles in the western Mediterranean Sea could be explained by a migratory hypothesis, that is, some young turtles found in that area could come from Atlantic populations and have penetrated into the western Mediterranean Sea through the Strait of Gibraltar (Camiñas, 1992, 1995, 1997b; Bolton et al., 1998). By this line of reasoning, it could be interesting to study the epizoic algae growing on loggerhead turtles of the western Mediterranean Sea, in order to distinguish the Atlantic from the eastern Mediterranean populations of loggerhead turtles. Thus, $P$. carettia could be used as a biological marker to distinguish the loggerhead turtles coming from the Atlantic Ocean and found in the western Mediterranean Sea, from those coming from the eastern Mediterranean 
Sea. However, it is necessary to study many more samples of algae growing on loggerhead turtles from both the western and eastern Mediterranean Sea in order to test this hypothesis.

The samples of $P$. carettia studied show rhizoids that when fully developed were cut off by a cross wall, in agreement with the observations from Rojas-González et al. (1994). In the original description of the taxon, Hollenberg (1971) described rhizoids that were not cut off by a cross wall (as shown in fig. 3.2 ), but based on these more recent observations we believe that this character in the original description must be revised (see fig. 3.3). On the other hand, our samples are bigger (up to $4 \mathrm{~cm}$ in length) than the thalli found in the Canary Islands by Rojas-González (1997) (up to $2 \mathrm{~cm}$ in length) and with tetrasporangia of greater diameter.

ACKNOWLEDGEMENTS. This study was supported by two projects from the Oceanographic Centre of Málaga of the Instituto Español de Oceanografía (IEO), in cooperation with European countries, and co-financially supported by the European Union: Project EMTP (Assessing marine turtle bycatch in European drifting longline and trawl fisheries for identifying fishing regulations) and Project SWOMED (Swordfish fisheries in the Mediterranean Sea). We thank to José Miguel de la Serna and Dr. David Macías (Oceanographic Centre of Málaga of the IEO) the data cession about the SWOMED Project. We also thanks to the skipper of the fishing boat "Nuevo Taconeo", Antonio Lozano Gómez, as well as its crew for their help on board during sampling periods. Dr. Antonio Secilla (Dpto. Biología Vegetal y Ecología, Universidad del País Vasco) confirmed the identification of Polysiphonia carettia. Dr. Eric C. Henry (Herbarium, Department of Botany and Plant Pathology, Oregon State University, Corvallis, Oregon, USA) kindly revised the style and English usage.

\section{REFERENCES}

ABEL SENTÍES, G., J. ESPINOZA-AVALOS \& J.C. ZURITA - 1999- Epizoic algae of nesting sea turtles Caretta caretta (L.) and Chelonia mydas (L.) from the Mexican Caribbean. $B$. mar. sci. 64: 185-188.

BOLTON, A.B., K.A. BJORNDAL, H.R. MARTINS, T. DELLINGER \& M.J. BISCOITO -1998- Transatlantic developmental migrations of loggerhead sea turtle demonstrated by mtDNA sequence analysis. Ecol. appl. 8: 1-7.

CAINE, E. A. -1986- Caparace epibionts of nesting loggerhead sea turties: Atlantic coast of U.S.A. J. exp. mar. Biol. Ecol. 95: 15-26.

CAMIÑAS, J.A. -1992- Hipótesis migratoria de la tortuga boba (Caretta caretta) en el Mediterráneo occidental a partir de datos procedentes de pesquerías superficiales. I Congreso Nacional de Reptiles marinos. Begur (Girona).

CAMIÑAS, J.A - 1995- The loggerhead Caretta caretta (Linnaeus, 1758) pelagic movements through the Gibraltar Strait. Rapp. Comm. Int Mer Médit. 34: 238.

CAMIÑAS, J.A. -1997a- Capturas accidentales de tortuga boba Caretta caretta (Linnaeus, 1758) en el Mediterráneo occidental en la pesquería de palangre de superficie de pez espada (Xiphias gladius L.). International Commission for the Conservation of Atlantic tunas. Collective Volume of Scientific Papers, vol. XLVI (4): 446-455.

CAMIÑAS, J.A. -1997b- Relación entre las poblaciones de la tortuga boba Caretta caretta (Linnaeus, 1758) procedentes del Atlántico y del Mediterráneo en la región del Estrecho de Gibraltar y áreas adyacentes. Rev. Esp. Herp. 11: 91-98.

CRIBB, A.B. -1969- Algae on a Hawk's-Bill turtles in Nothern Australia. Aust. Zool., 15: 150-159.

DODD, C.K -1988- Synopsis of the biological data on the loggerhead sea turtle Caretta caretta (Linnaeus 1758). United States Fish and Wildlife Service, Biological Report 88(14): 110pp.

FRAIZER, J., D. MARGARITOULIS, K. MULDOON, C.W. POTTER, J. ROSEWATER, C. RUCKDESCHEL \& S. SALAS -1985Epizoan communities on marine turtles: I. Bivalve and Gastropod mollusks. Mar. Ecol. P.S.Z.N.I., 6(2): 127-140.

FRICK, M.G., K.L. WILLIAMS \& M. ROBINSON -1998-Epibionts associated with nesting loggerhead sea turtles (Caretta caretta) in Georgia, USA. Herpetological Review 29(4): 
211-214.

FRICK, M.G., K.L. WILLIAMS, D. VELJACIC, L. PIERRARD, J.A. JACKSON \& S.E. KNIGHT 2000- Newly documented epibiont species from nesting loggerhead sea turtles (Caretta caretta) in Georgia, USA. Marine Turtle Newsletter 88: 3-5.

HOLLENBERG, G.J. - 1971- Phycological notes. V. New species of marine algae from California. Phycologia 10: 11-16.

HOLLENBERG, G.J. \& J.N. NORRIS - 1977- The red alga Polysiphonia (Rhodomelaceae) in the Northern Gulf of California. Smith. Contrib. Mar. Sci. 1: 1-21.

LAURENT, L., P. CASALE, M.N. BRADAI, B.J. GODLEY, G. GEROSA, A.C. BRODERICK, W. SCHROTH, B. SCHIERWATER, A. M. LEVY, D. FREGGI, E.M. ABD EL-MAWLA, D.A. HADOUD, H.E. GOMATI, M. DOMINGO, M. HADJICHRISTOPHOROU, L. KORNARAKY, F. DEMIRAYAK \& CH. GAUTIER -1998- Molecular resolution of marine turtle stock composition in fishery bycatch: a case study in the Mediterranean. Mol. Ecol. 7: 1529-1542.

MARGARITOULIS, D. -1982- Observations on loggerhead sea turtles (Caretta caretta) activity during the nesting seasons (1977-1979) in Zakynthos, Greece. Biol. Conserv. 24: 193-204.

MÁRQUEZ, M.R. -1990- FAO Species catalogue. Sea turtles of the world. An annotated and illustrated catalogue of sea turtle species known to date. FAO Fisheries Synopsis, 125. Rome, FAO. Vol.: 11.

ROJAS-GONZÁLEZ, B. -1997- Estudio de las especies de la Familia Rhodomelaceae (Rhodophyta), con exclusión de las Tribus Chondriaceae y Laurencieae, en las Islas Canarias. Ph. D. thesis. Univ. La Laguna. La Laguna, Canary Islands.
ROJAS-GONZÁLEZ, B., J. AFONSO-CARRILLO \& C. IBEAS -1994- New records of Rhodomelaceae (Rhodophyta) from the Canary Islands. Bot. Mar. 37: 133-138.

Aceptado para su publicación en noviembre de 2001

Author's Addresses. J.C. BÁEZ, F. CONDE and A. FLORES-MOYA: Departamento de Biología Vegetal, Facultad de Ciencias, Universidad de Málaga, Campus de Teatinos s/n, 29071 Málaga, Spain. J.A. CAMIÑAS and J. VALEIRAS: Instituto Español de Oceanografía, Centro Oceanográfico de Málaga, Puerto Pesquero s/n, 29640 Fuengirola (Málaga), Spain. 